\title{
Solvent Extraction of Nickel and Cobalt from Ammonia-Ammonium Carbonate Solution by Using LIX 84-ICNS
}

\author{
Mohammad Zaki Mubarok*, Fariza Eka Yunita \\ Department of Metallurgical Engineering, Faculty of Mining and Petroleum Engineering, Institut Teknologi \\ Bandung, Bandung, Indonesia \\ Email: zaki@mining.itb.ac.id
}

Received 8 March 2015; accepted 15 June 2015; published 18 June 2015

Copyright (C) 2015 by authors and Scientific Research Publishing Inc.

This work is licensed under the Creative Commons Attribution International License (CC BY). http://creativecommons.org/licenses/by/4.0/

c) (i) Open Access

\begin{abstract}
In the present paper, separation of nickel and cobalt in ammonia-ammonium carbonate solution that simulates pregnant leach solution of Caron Process by solvent extraction using LIX 84-ICNS was studied. LIX 84-ICNS is a novel extractant which is still being studied, especially for nickel and cobalt separation in ammonia-ammonium carbonate solution. A series of solvent extraction tests were performed at various equilibrium $\mathrm{pH}$, temperature, extractant concentration, and volume ratio of organic to aqueous solution ( $0 / A$ ratio). The investigation results show that the highest nickel and cobalt extraction percentages of $99.8 \%$ and $90.3 \%$ were obtained from the extraction test at equilibrium $\mathrm{pH}$ of 8.75 , temperature of $55^{\circ} \mathrm{C}$, extractant concentration of $40 \%(\mathrm{v} / \mathrm{v})$ and $0 / \mathrm{A}$ ratio of $1 / 1$, respectively. Oxidation of cobalt in aqueous solution prior to extraction is needed to minimize co-extraction of cobalt. Co-extracted cobalt can be decreased from $90.3 \%$ to $30.3 \%$ by mixing $1 \%(\mathrm{v} / \mathrm{v}) \mathrm{H}_{2} \mathrm{O}_{2}$ in aqueous solution prior to the extraction stage. It was found that nickel and cobalt extractions by LIX 84-ICNS are endothermic processes with enthalpy changes of +171.03 and $+7.64 \mathrm{~kJ} /$ mole, respectively. Based on constructed McCabe-Thiele Diagram, nickel extraction level of more than $99.9 \%$ can be obtained in 2 stages at $0 / A$ ratio of 0.5 . The highest stripping percentages of nickel and cobalt of $98.82 \%$ and $3.16 \%$, respectively were obtained at $200 \mathrm{~g} / \mathrm{l} \mathrm{H}_{2} \mathrm{SO}_{4}$ as stripping agent.
\end{abstract}

\section{Keywords}

Nickel, Cobalt, Ammonia-Ammonium Carbonate, Solvent Extraction, LIX 84-ICNS

\footnotetext{
${ }^{*}$ Corresponding author.
} 


\section{Introduction}

Laterite ore is a major primary source of nickel and cobalt production along with sulfide ore. There are various processes that have been implemented for extracting nickel from laterite ore. Basically, those processing technologies use pyrometallurgy, hydrometallurgy or a combination of these routes dependent on the ore type, the availability of energy and some other specific factors [1]. A major pyrometallurgical process for nickel laterite ore is Elkem process which uses rotary dryer-rotary kiln and electric furnace to produce ferronickel or nickel matte. Elkem process usually treats high-grade saprolite ore. In addition to ferronickel and nickel matte, some other product types produced by pyrometallurgical routes are nickel pig iron (NPI) and sponge ferronickel or so-called nickel luppen [1] [2]. In contrast to hydrometallurgical processes, the above-mentioned pyrometallurgical processes cannot recover cobalt as separate by-product.

Hydrometallurgical route is commonly used to treat low-grade laterite ore of limonitic type which has relatively higher iron and cobalt contents. There are two major hydrometallurgical processing technologies that have been proven and used in industrial scale for a long time, namely Caron Process and HPAL (High Pressure Acid Leaching). Caron Process involves drying, reduction roasting of nickel laterite ores followed by leaching in ammonia-ammonium carbonate solution. Caron Process has several advantages in comparison to HPAL in terms of the susceptibility of the equipments to corrosion and the amount of the waste slurry. On the other hand, high temperatures and energy-intensive processes in upstream and downstream stages (i.e. drying, reduction roasting and nickel metal oxide reduction to nickel metal) are the drawbacks that reduce the competitiveness of Caron Process [1]. Various developments have been made to perform acid leaching of laterite ore at atmospheric pressure. The efforts are aimed at increasing leaching selectivity to iron for minimizing acid consumption as well as acid regeneration in atmospheric leaching processes using hydrochloric and nitric acids [3]-[5].

Separation of cobalt and nickel in pregnant leach solution, either in ammonia-based or sulfuric acid solution is a difficult task due to relatively similar behaviour of these metals. Various methods for the separation of nickel and cobalt in aqueous solutions have been developed which include chemical precipitation, selective adsorption onto ion exchange resins and solvent extraction (SX). Among these methods, SX is the most frequently used technique because of its high separation factor and capacity and its compatibility with electrowinning.

Since 1980s, a number of extractants for separations of nickel and cobalt in ammoniacal solutions such as $\beta$-diketone [6] [7] and hydroxyoximes (e.g. LIX84 [8], LIX84-I [9], Acorga M5640 [10] [11], and LIX84-INS [12]) have been studied. Solvent extraction technique has been successfully implemented for separation of nickel from cobalt in ammoniacal solution at Queensland Nickel Pty Ltd., Yabulu and Cawse Nickel Mine of Norilsk Nickel, both in Australia [12]-[15].

In the present work, separation of nickel and cobalt by solvent extraction using LIX 84-ICNS in ammonia-ammonium carbonate solution that simulates pregnant leach solution of Caron Process is discussed. LIX 84-ICNS is a novel product of BASF; its performance is still under study, especially for nickel and cobalt separation in ammonium-based solution. Key parameters of Ni-Co solvent extraction using this extractant in ammoniacal solution such as $\mathrm{Ni}$ and Co distribution coefficients $\left(\mathrm{D}_{\mathrm{Ni}}\right.$ and $\left.\mathrm{D}_{\mathrm{Co}}\right)$, separation factor of Ni-Co $\left(\beta_{\mathrm{Ni}-\mathrm{Co}_{0}}\right)$, the effects of SX variables (i.e. $\mathrm{pH}$, extractant concentration, temperature, volume ratio of organic to aqueous solution) on nickel and cobalt extraction behaviour must be elucidated. It should be noted that separation of nickel and cobalt by SX in ammonia-ammonium carbonate solution is not only applicable for the pregnant-leach solution from Caron Process but also for the solution produced by re-leaching of mixed hydroxide precipitate (MHP) or mixed sulphide precipitate (MSP) from HPAL process in ammonia-ammonium carbonate solution.

\section{Experimental}

\subsection{Materials}

The solution of LIX 84-ICNS (2-hydroxy-5-nonylacetophenone oxime) extractant and shellsol as diluent were kindly donated by PT BASF Indonesia. Chemical structure of LIX 84-ICNS is illustrated in Figure 1. Technical specification of the extractant is presented in Table 1. The extractant and the diluent were used as received without any further purification. Nickel sulphate hexahydrate $\left(\mathrm{NiSO}_{4} \cdot 6 \mathrm{H}_{2} \mathrm{O}\right)$, cobalt sulphate heptahydrate $\left(\mathrm{CoSO}_{4} \cdot 7 \mathrm{H}_{2} \mathrm{O}\right)$, ammonium carbonate $\left(\left(\mathrm{NH}_{4}\right)_{2} \mathrm{CO}_{3}\right)$, ammonia solution $\left(\mathrm{NH}_{3}\right)$ and sulphuric acid solution $\left(\mathrm{H}_{2} \mathrm{SO}_{4}\right)$ of analytical reagent grades were used for preparation of materials used in the testworks. A solution which contains $12 \mathrm{~g} / \mathrm{l} \mathrm{Ni}, 1 \mathrm{~g} / \mathrm{l} \mathrm{Co}, 45 \mathrm{~g} / \mathrm{l} \mathrm{NH}_{3}$ and $25 \mathrm{~g} / \mathrm{l} \mathrm{CO}$ was prepared that simulates a pregnant-leach solution of 


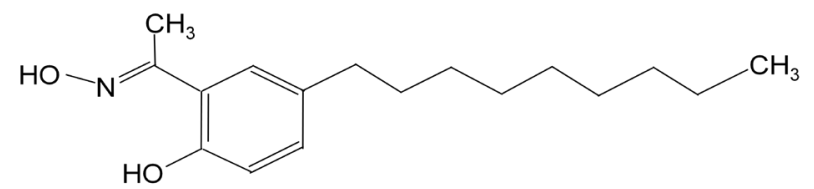

Figure 1. Chemical structure of LIX 84-ICNS [18].

Table 1. Technical specification of LIX 84-ICNS [18].

\begin{tabular}{cc}
\hline Parameter & Value \\
Specific gravity & $0.945-0.965 \mathrm{gram} / \mathrm{cm}^{3}$ \\
Flame temperature & $>170^{\circ} \mathrm{F}$ \\
Maximum Ni loading & $14.1-15.3 \mathrm{~g} / \mathrm{l}$ \\
Ni extraction isotherm & $\geq 13.5 \mathrm{~g} / \mathrm{l}$ \\
Extraction kinetics & $\geq 95 \%(30$ second $)$ \\
Separation factor of Ni-Zn & $\geq 50,000$ \\
Phase separation during extraction & $\leq 4 \mathrm{minute}$ \\
Ni stripping isotherm & $\leq 0.1 \mathrm{~g} / \mathrm{l}$ \\
Stripping kinetics & $\geq 92 \%$ (10 minute) \\
Phase separation during stripping & $\leq 100 \mathrm{~second}$ \\
Ammonia loading & $\leq 1.5 \mathrm{~g} / \mathrm{l}$
\end{tabular}

Caron Process. A solution which contains $12 \mathrm{~g} / \mathrm{l} \mathrm{Ni}, 1 \mathrm{~g} / \mathrm{l} \mathrm{Co}, 45 \mathrm{~g} / \mathrm{l} \mathrm{NH} 3$ and $25 \mathrm{~g} / \mathrm{l} \mathrm{CO} \mathrm{CO}_{2}$ was prepared that simulates a pregnant-leach solution of Caron Process [14]. The desired solution $\mathrm{pH}$ was adjusted by ammonia and sulphuric acid solution. Sulphuric acid was also used as stripping agent.

\subsection{Methods}

Series of extraction and stripping testworks have been conducted by using the earlier mentioned extractant and prepared solutions. In both stages, $50 \mathrm{~cm}^{3}$ of aqueous solution was contacted in a $250 \mathrm{~cm}^{3}$ beaker glass using a mechanical agitator from IKA Instrument. The agitations were performed for a sufficient period of time to attain equilibrium $\mathrm{pH}$ of the aqueous phase. The $\mathrm{pH}$ of aqueous phase was measured by using a $\mathrm{pH}$-meter from Mettler-Toledo. Solution temperature was maintained at $30^{\circ} \mathrm{C}$, except it is mentioned that the experiment is done at higher temperatures. After stirring was finished, the aqueous solution was separated from the loaded extractant by using a separator funnel. Concentrations of nickel and cobalt in the aqueous phase were measured by Atomic Absorption Spectrophotometer (AAS). The concentrations of nickel and cobalt in organic phase at equilibrium state were calculated from the difference of the initial metals concentrations in aqueous solution and its concentrations in aqueous phase at the equilibrium.

The extraction tests were performed at various equilibrium $\mathrm{pH}$, temperature, extractant concentration, and volume ratio of organic to aqueous solution (O/A ratio). To minimize co-extraction of cobalt and improving extraction selectivity, series of pre-oxidations of $\mathrm{Co}^{2+}$ to $\mathrm{Co}^{3+}$ testworks were also conducted prior to the extraction stage. After the extraction testworks were finished, series of stripping testworks were carried out under various $\mathrm{H}_{2} \mathrm{SO}_{4}$ concentration and O/A ratios. Isothermal extraction, isothermal stripping, and McCabe-Thiele Diagrams were constructed to determine O/A ratio and hypothetic stages required to obtain maximum nickel extraction and stripping.

\section{Results and Discussion}

\subsection{Effect of $\mathrm{pH}$}

The $\mathrm{pH}$ of aqueous solution was adjusted to values ranging between 8.0 and 9.50 using sulphuric acid or ammonia solution. Single stage extraction was carried out at $55^{\circ} \mathrm{C}$, O/A ratio $1 / 1$ and $40 \%$ (v/v) LIX 84-ICNS. Profiles 
of extracted $\mathrm{Ni}$ and $\mathrm{Co}$ as a function of equilibrium $\mathrm{pH}$ are presented in Figure 2. The experimental results show that the extraction percentages of nickel and cobalt rises by the increased of equilibrium $\mathrm{pH}$ values. Maximum extracted nickel and cobalt of $99.8 \%$ and $90.3 \%$ were obtained at equilibrium $\mathrm{pH} 8.75$, respectively. At this $\mathrm{pH}$ level, $\mathrm{D}_{\mathrm{Ni}}, \mathrm{D}_{\mathrm{Co}}$ and $\beta_{\mathrm{Ni}-\mathrm{Co}}$ are 548.3, 9.3 and 58.9, respectively. Profiles of $\mathrm{D}_{\mathrm{Ni}}, \mathrm{D}_{\mathrm{Co}}$ and $\beta_{\mathrm{Ni}-\mathrm{Co}}$ as a function of equilibrium $\mathrm{pH}$ at $55^{\circ} \mathrm{C}$, O/A ratio $1 / 1$ and $40 \%$ (v/v) LIX 84-ICNS are depicted in Figure 3. Extraction of nickel by LIX 84-ICNS performs through the following reaction:

$$
2 \mathrm{RH}_{(o)}+\mathrm{Ni}\left(\mathrm{NH}_{3}\right)_{x(a)}^{2+} \rightarrow \mathrm{R}_{2} \mathrm{Ni}_{(o)}+2 \mathrm{H}_{(a)}^{+}+x \mathrm{NH}_{3(a)}
$$

As has been formulated by Equation (1), during Ni extraction from aqueous solution and the formation of nickel-ammine complex ion, hydrogen ion is released by the extractant to the aqueous phase, which consequently reduces the $\mathrm{pH}$ of aqueous solution. If $\mathrm{pH}$ adjustment is not conducted, the lowering $\mathrm{pH}$ of aqueous solution would drive the reaction back to the left-side (releasing of metal ions back to the aqueous phase).

The experimental results show that at $\mathrm{pH}$ levels above 8.75, the extraction percentages of nickel and cobalt decreased. At $\mathrm{pH}$ levels above 8.75, the solution $\mathrm{pH}$ was adjusted with $\mathrm{NH}_{3}$ addition. According to Equation (1), the excess of $\mathrm{NH}_{3}$ will induce the reaction back to the left-side and tends to inhibit metal transfer to organic

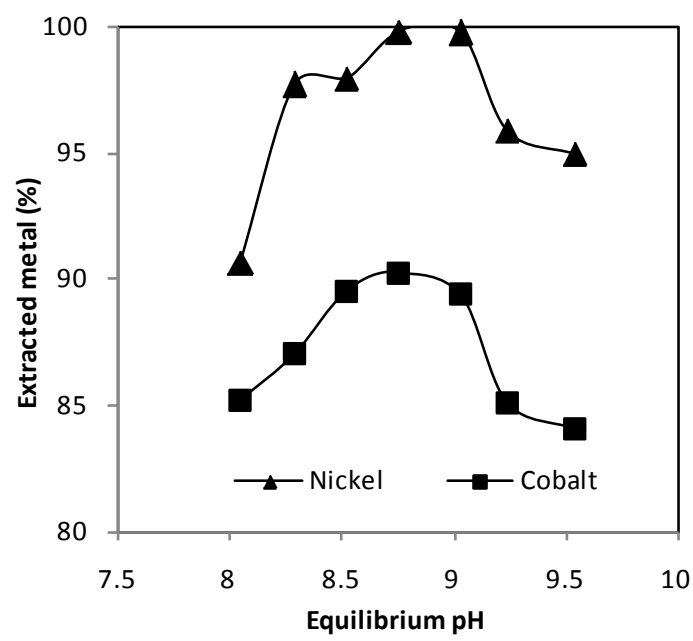

Figure 2. Profiles of extracted $\mathrm{Ni}$ and $\mathrm{Co}$ as a function of equilibrium $\mathrm{pH}$ at $55^{\circ} \mathrm{C}, \mathrm{O} / \mathrm{A} 1 / 1$ and $40 \%$ (v/v) LIX 84-ICNS.

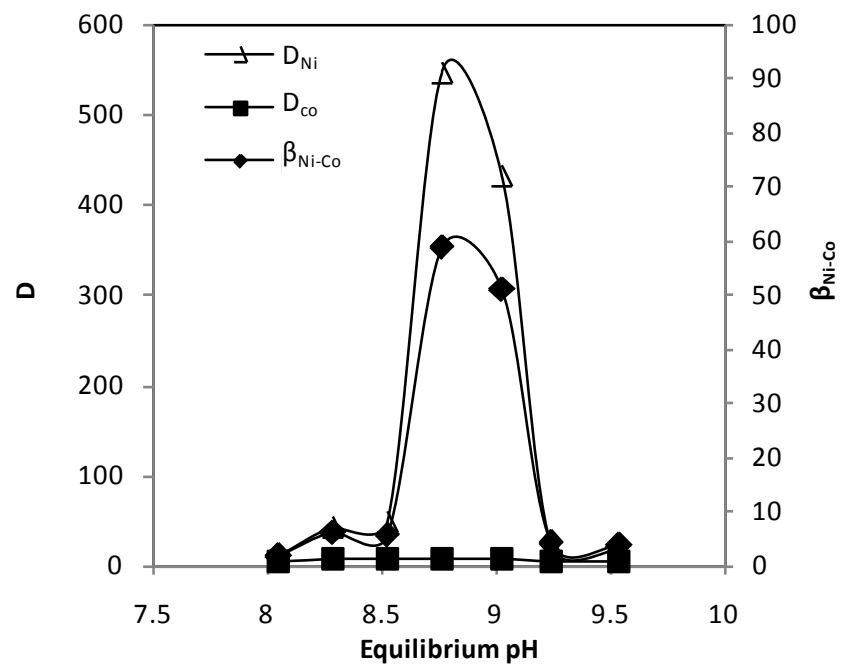

Figure 3. Profiles of $\mathrm{D}_{\mathrm{Ni}}, \mathrm{D}_{\mathrm{Co}}$ and $\beta_{\mathrm{Ni}-\mathrm{Co}}$ as a function of equilibrium $\mathrm{pH}$ at $55^{\circ} \mathrm{C}, \mathrm{O} / \mathrm{A}$ ratio $1 / 1$ and $40 \%$ (v/v) LIX 84-ICNS. 
phase. The alteration of ammonia concentration by addition of $\mathrm{NH}_{3}$ for $\mathrm{pH}$ adjustment gives higher impact to nickel than that to cobalt. Nickel ammonia complexes are reported to be more stable than those of cobalt [7]. Nickel can form various Ni-ammine complexes such as di-ammine, tetra-ammine and hexa-ammine. The type of $\mathrm{Ni}$-ammine complex is dependent on the solution $\mathrm{pH}$. Following $\mathrm{Hu}$, at $\mathrm{pH}$ 8.5, nickel forms a complex of nickel tetra-ammine [7]. The formation of nickel tetra-ammine is the reason for the decreased of Ni extraction obtained at equilibrium $\mathrm{pH}$ above 8.75. Decreasing metal extractions during $\mathrm{SX}$ in ammoniacal solutions beyond $\mathrm{pH} 8.4$ were reported by Nathsarma and Sarma [16] beyond pH 8.5 by Hu, et al. [7] and beyond $\mathrm{pH} 9$ by Alguacil and Cobo [17]. According to $\mathrm{Hu}$, et al., at $\mathrm{pH}$ 8.5, the predominant species is nickel tetra-ammine complex and the average coordination number of ammonia per mole of nickel ion is approximately 4 , therefore, the decrease of nickel extraction is mainly attributed to the formation of nickel ammine species with ammonia ligands of more than 4 which is more stable in aqueous solution [7].

\subsection{Effect of Temperature}

Single stage extractions of nickel and cobalt from ammonia-ammonium carbonate solution using $40 \%(\mathrm{v} / \mathrm{v})$ LIX 84-ICNS and O/A $1 / 1$ were carried out at temperatures $25^{\circ} \mathrm{C}, 40^{\circ} \mathrm{C}$ and $55^{\circ} \mathrm{C}$ and various equilibrium $\mathrm{pH}$. Profiles of nickel and cobalt extractions as a function of temperature and equilibrium $\mathrm{pH}$ are depicted in Figure 4. Theoretically, the increase of temperature tends to enhance equilibrium concentration of metal ions that can be extracted to organic phase. Moreover, at higher temperatures, the solubility of the organic phase in aqueous solution and the viscosity of organic solution is lower that leads to a better contact between the organic and the aqueous phases during mixing. The extraction is usually operated up to $80^{\circ} \mathrm{C}-85^{\circ} \mathrm{C}$. The operations at higher temperatures might cause degradation of the organic solution.

As can be seen in Figure 4, the increase of temperature increases both nickel and cobalt extractions. Hence, the increase of temperature enhances also distribution coefficients of nickel $\left(\mathrm{D}_{\mathrm{Ni}}\right)$ and cobalt $\left(\mathrm{D}_{\mathrm{Co}}\right)$. Profiles of $\log D$ versus $(1 / T)$ for nickel and cobalt at equilibrium $\mathrm{pH}$ of 8.75 are illustrated in Figure 5 . Linier regression lines of $\log D$ versus $(1 / T)$ for nickel and cobalt have a slope of -8.93 and -0.40 , respectively which indicates that temperature give more significant influence to nickel extraction than to cobalt. The effect of temperature on equilibrium constant and the change of enthalpy $(\Delta H)$ of the extraction reaction follow a prominent Van't Hoff Equation:

$$
\frac{\partial \log K}{\partial(1 / T)}=-\frac{\Delta H}{2.303 R}
$$

in which $K$ is equilibrium constant of extraction reaction, $T$ absolute temperature and $R$ ideal gas constant.

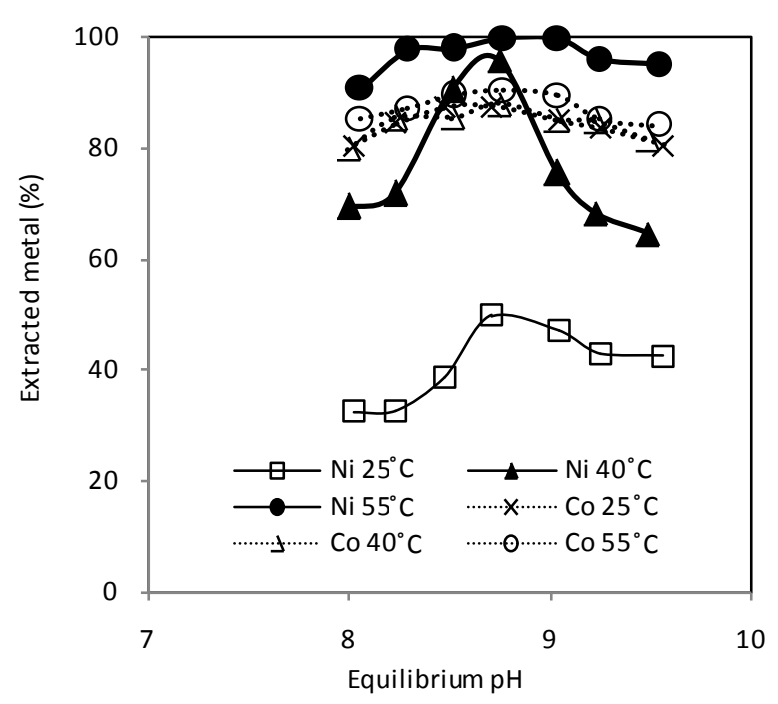

Figure 4. Profiles of $\mathrm{D}_{\mathrm{Ni}}, \mathrm{D}_{\mathrm{Co}}$ and $\beta_{\mathrm{Ni}-\mathrm{Co}}$ as a function of equilibrium $\mathrm{pH}$ at $55^{\circ} \mathrm{C}, \mathrm{O} / \mathrm{A}$ ratio $1 / 1$ and $40 \%(\mathrm{v} / \mathrm{v}) \mathrm{LIX}$ 84-ICNS. 


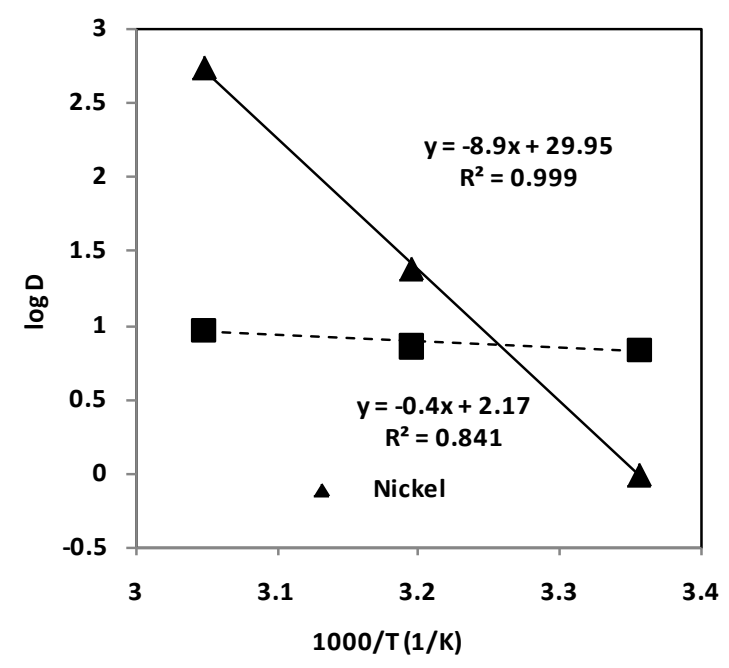

Figure 5. Profiles of $\log D$ versus $1 / T$ for $\mathrm{Ni}$ and $\mathrm{Co}$ extraction at $\mathrm{pH} 8.75, \mathrm{O} / \mathrm{A} 1 / 1$ and $40 \%$ (v/v) LIX 84-ICNS.

The equilibrium constant for Reaction (1) is as follow:

$$
K_{e x}=\frac{\left[\mathrm{R}_{2} \mathrm{Ni}\right]_{o}\left[\mathrm{H}^{+}\right]_{a}^{2}\left[\mathrm{NH}_{3}\right]_{a}^{x}}{\left[\mathrm{Ni}\left(\mathrm{NH}_{3}\right)_{x}^{2+}\right]_{a}[\mathrm{RH}]_{o}^{2}}
$$

and its distribution ratio is defined as:

$$
D=\frac{\left[\mathrm{R}_{2} \mathrm{Ni}_{o}\right.}{\left[\mathrm{Ni}\left(\mathrm{NH}_{3}\right)_{x}^{2+}\right]_{a}}
$$

in which $\left[\mathrm{R}_{2} \mathrm{Ni}\right]_{o}$ and $\left[\mathrm{Ni}\left(\mathrm{NH}_{3}\right)_{x}^{2+}\right]$ are nickel concentrations in organic phase and aqueous phase at equilibrium, respectively. At constants ammonia and extractant concentrations and aqueous solution $\mathrm{pH}$, the following correlation is obtained:

$$
K=D C_{1}
$$

in which $C_{1}$ is a constant. The following is the integrated form of Equation (2):

$$
\log K=-\frac{\Delta H}{2.303 R} \frac{1}{T}+C_{2}
$$

By substituting Equation (5) to Equation (6) the followings equation are obtained:

$$
\begin{gathered}
\log \left(D C_{1}\right)=-\frac{\Delta H}{2.303 R} \frac{1}{T}+C_{2} \\
\log D+\log C_{1}=-\frac{\Delta H}{2.303 R} \frac{1}{T}+C_{2} \\
\log D=-\frac{\Delta H}{2.303 R} \frac{1}{T}+C
\end{gathered}
$$

in which $C=C_{1}+C_{2}$. The differential form of Equation (7) against (1/T) can be re-written as follow:

$$
\frac{\partial \log D}{\partial(1 / T)}=-\frac{\Delta H}{2.303 R}
$$


The value of $\Delta H$ can be determined from the slope of linear plot of $\log D$ versus $(1 / T)$ in which the slope is the value of $-\Delta H /(2.303 \mathrm{R})$. From the profiles of $\log D$ versus $(1 / T)$ for nickel and cobalt presented in Figure 5 , the values of $\Delta H$ obtained for nickel and cobalt extractions are +171.03 and $+7.64 \mathrm{~kJ} / \mathrm{mole}$, respectively. The positive values of $\Delta H$ for $\mathrm{Ni}$ and Co extractions indicate that the extractions of $\mathrm{Ni}$ and $\mathrm{Co}$ from ammonia-ammonium carbonate solution by LIX 84-ICNS are endothermic reactions. This implies that the increase of temperature would drive the reaction to the right-side (i.e. improving extractions of $\mathrm{Ni}$ and $\mathrm{Co}$ ) with more impact on Ni extraction.

\subsection{Effect of Extractant Concentration}

In practice, less amount of extractant used is attempted to have more competitive process in financial point of view. The investigation results show that nickel and cobalt extractions are only $65.6 \%$ and $84.7 \%$, respectively, when the concentration of LIX 84-ICNS is $10 \%(\mathrm{v} / \mathrm{v})$ at equilibrium $\mathrm{pH}$ of $8.75,55^{\circ} \mathrm{C}$ and $\mathrm{O} / \mathrm{A}$ ratio of $1 / 1$. In order to determine suitable extractant concentration for achieving higher nickel extraction, the extractant concentration was varied at $10 \%, 20 \%$ and $40 \%$ (v/v). Profiles of nickel and cobalt extraction as a function of equilibrium $\mathrm{pH}$ at various extractant concentrations are presented in Figure 6 and Figure 7, respectively. As expected, the extractions of nickel and cobalt increase by the increased of extractant concentration. The higher metals extraction at higher extractant concentrations is in-line with Equation (1) and (3), in which the increase of extractant concentration would shift the equilibrium reaction to the right-side that leads to the enhanced of metal extraction.

\subsection{Effect of Pre-Oxidation of Aqueous Solution Prior to Extraction}

It can be seen that cobalt co-extractions at various conditions presented earlier are relatively high. Therefore, series of pre-oxidations of cobalt in aqueous solution were carried out prior to the extraction stage. Divalent cobalt in aqueous solution was oxidized to trivalent form by three different methods, namely air exposure for $48 \mathrm{~h}$ prior to extraction, solution aeration and oxidation using hydrogen peroxide $\left(\mathrm{H}_{2} \mathrm{O}_{2}\right)$. Although both cobalt and nickel exist as divalent ions in aqueous solution, the trivalent cobalt ion tends to form in preference to nickel when the aqueous solution is being oxidized. This difference tendency of nickel and cobalt to form trivalent cation provides a basis for separation of these metals in ammoniacal solution using LIX 84-ICNS since the extractant only extracting $\mathrm{Co}^{2+}$ and does not reacts with $\mathrm{Co}^{3+}$. Effects of various pre-treatment methods on Ni and Co extractions are illustrated in Figure 8 and Figure 9, respectively. The extraction testworks were conducted at $55^{\circ} \mathrm{C}, 40 \%$ (v/v) LIX 84-ICNS and O/A ratio of 1/1.

As can be seen in Figure 8, pre-oxidation processes conducted prior to extraction does not notably influence nickel extraction. In contrast, cobalt extraction is significantly affected by pre-oxidation method of the aqueous

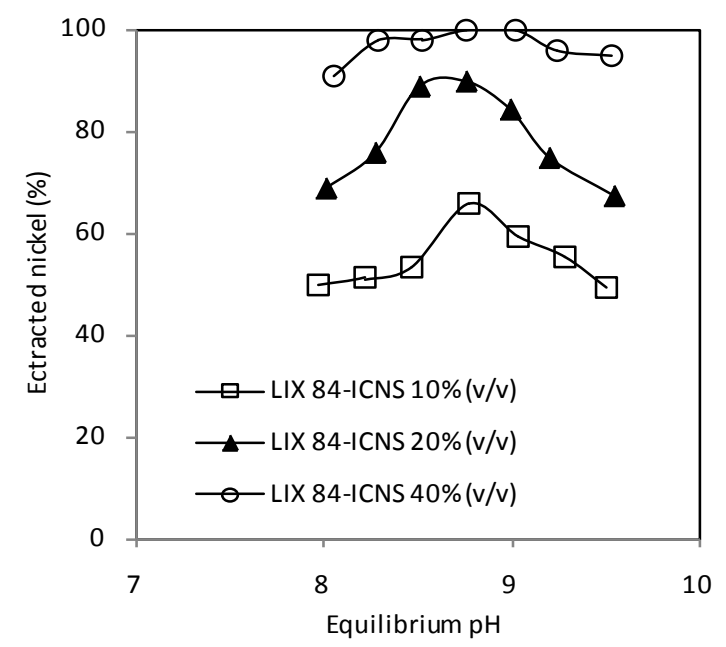

Figure 6. Profiles of nickel extraction as a function of equilibrium $\mathrm{pH}$ at various extractant concentrations, temperature $55^{\circ} \mathrm{C}, \mathrm{O} / \mathrm{A} 1 / 1$. 


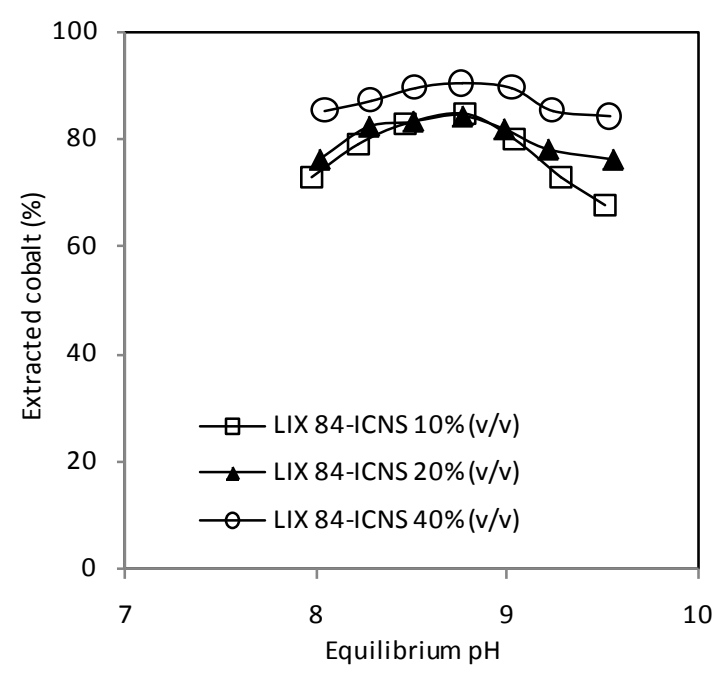

Figure 7. Profiles of cobalt extraction as a function of equilibrium $\mathrm{pH}$ at various extractant concentrations, temperature $55^{\circ} \mathrm{C}, \mathrm{O} / \mathrm{A} 1 / 1$.

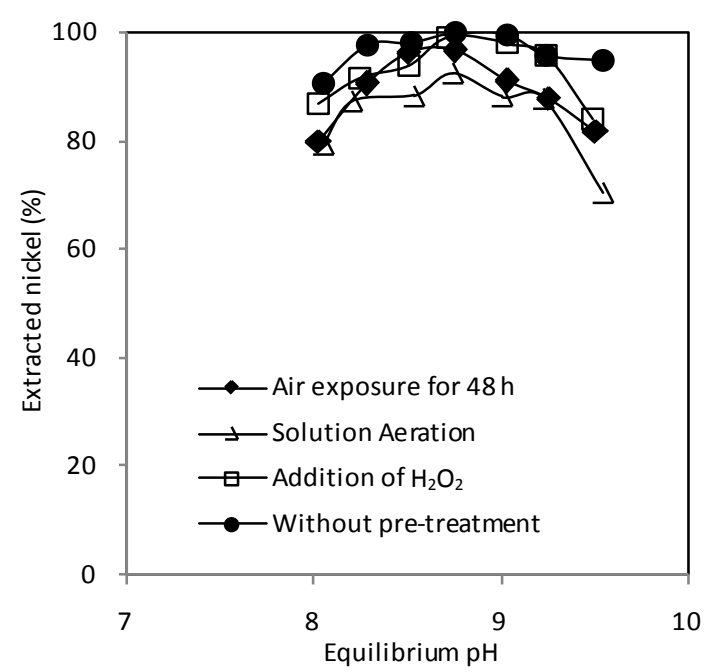

Figure 8. Effects of various pre-treatments of aqueous solutions on nickel extraction at $55^{\circ} \mathrm{C}, 40 \%(\mathrm{v} / \mathrm{v}) \mathrm{LIX}$ 84-ICNS and O/A ratio 1/1.

solution prior to the extraction stage. Cobalt extraction decreased from $90.3 \%$ to $55.3 \%$, $45.8 \%$, and $30.3 \%$, respectively after being treated by $48 \mathrm{~h}$ exposure of the aqueous solution in open-air prior to extraction, aeration for $1.5 \mathrm{~h}$ and oxidation using $0.5 \mathrm{ml}$ of $30 \mathrm{wt} \% \mathrm{H}_{2} \mathrm{O}_{2}$ in $50 \mathrm{~mL}$ of the aqueous solution. The oxidation using $1 \%$ $(\mathrm{v} / \mathrm{v})$ of $30 \mathrm{wt} \% \mathrm{H}_{2} \mathrm{O}_{2}$ increases separation factor of Ni-Co $\left(\beta_{\mathrm{Ni}-\mathrm{Co}}\right)$ from 58.95 without pre-treatments to 271.1 after being treated with $1 \%(\mathrm{v} / \mathrm{v}) \mathrm{H}_{2} \mathrm{O}_{2}$ (Figure 10). Further investigations are still required to reduce co-extracted cobalt in LIX 84-ICNS. Combined pre-oxidation have been conducted in QNI Pty Ltd., Yabulu, Australian in which the aqueous solution is aerated and followed by oxidation using $\mathrm{H}_{2} \mathrm{O}_{2}$ to oxidize the residual $\mathrm{Co}^{2+}$ prior to the extraction using LIX 87-QN extractant [14].

\subsection{Extraction Isotherm Diagram}

Extraction isotherm diagram for nickel was constructed based on the data obtained from the extraction testworks at equilibrium $\mathrm{pH}$ of 8.75 , temperature $55^{\circ} \mathrm{C}$, extractant concentration of $40 \%(\mathrm{v} / \mathrm{v}), \mathrm{O} / \mathrm{A}$ ratios of $0.2,0.4,0.6$, 0.8 and 1.0. An optimum O/A ratio must be determined in which high metal extraction at low O/A ratio is 


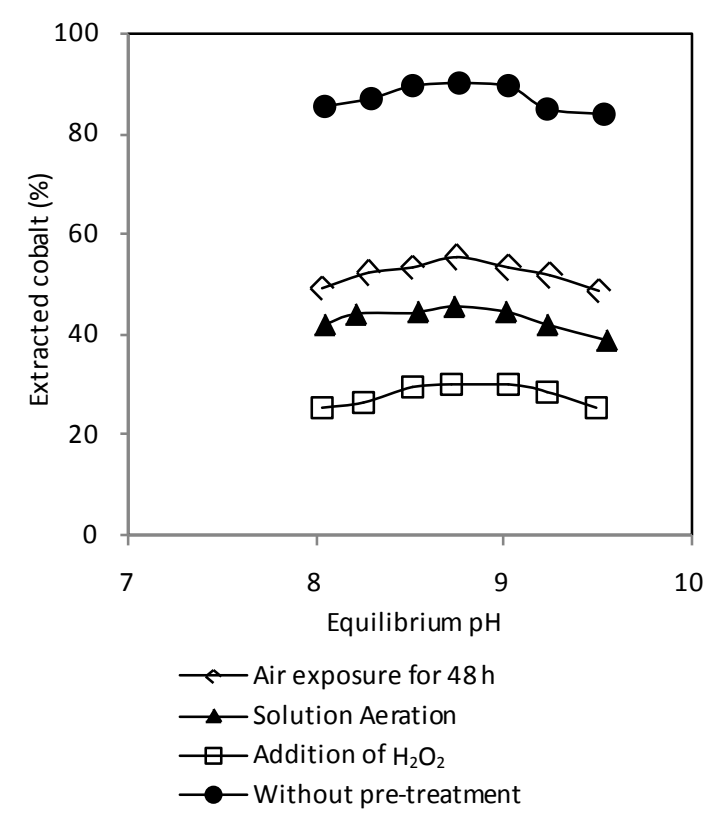

Figure 9. Effects of various pre-treatments of aqueous solutions on cobalt extraction at $55^{\circ} \mathrm{C} \mathrm{K}, 40 \%$ v/v LIX 84ICNS and $\mathrm{O} / \mathrm{A}$ ratio 1/1.

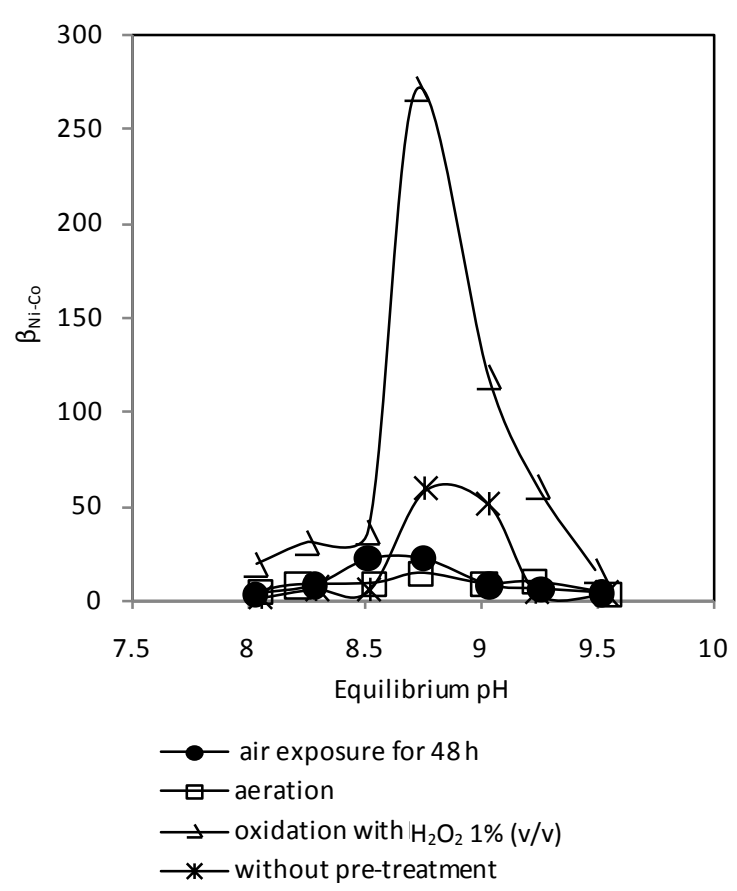

Figure 10. Separation factor of Ni-Co $\left(\beta_{\mathrm{Ni}-\mathrm{Co}}\right)$ as a function of equilibrium $\mathrm{pH}$ and pre-treatment methods of aqueous solution prior to extraction.

required for minimizing the organic extractant consumption and to provide higher metal concentration in organic phase. The influence of O/A ratio on nickel and cobalt extraction is shown in Figure 11. In order to determine O/A ratio and the hypothetic stages required to obtain maximum nickel extraction, McCabe-Thiele Diagram was constructed. Based on constructed McCabe-Thiele Diagram (Figure 12), it was found that nickel extraction levels of higher than $99.9 \%$ can be obtained in two stage extraction at equilibrium $\mathrm{pH}$ of 8.75 , temperature 


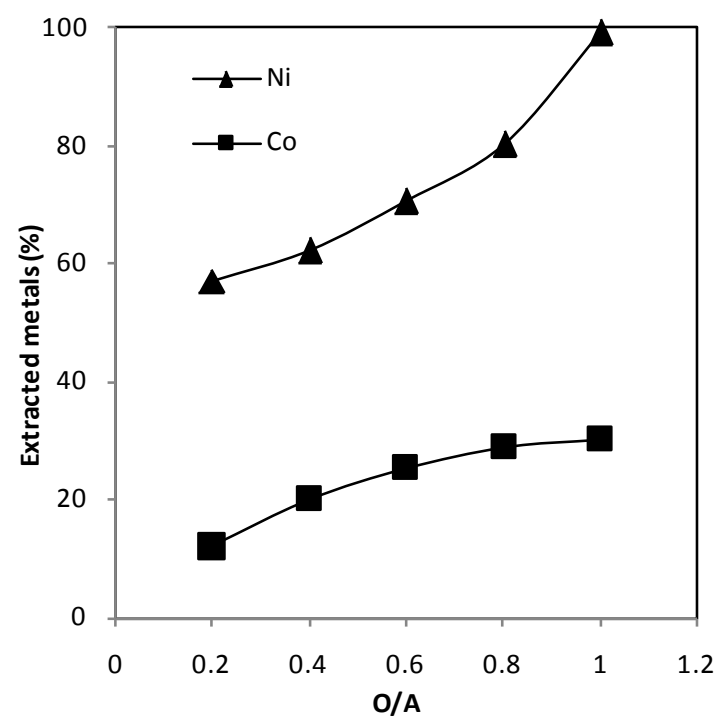

Figure 11. Influence of $\mathrm{O} / \mathrm{A}$ ratio on nickel and cobalt extractions.

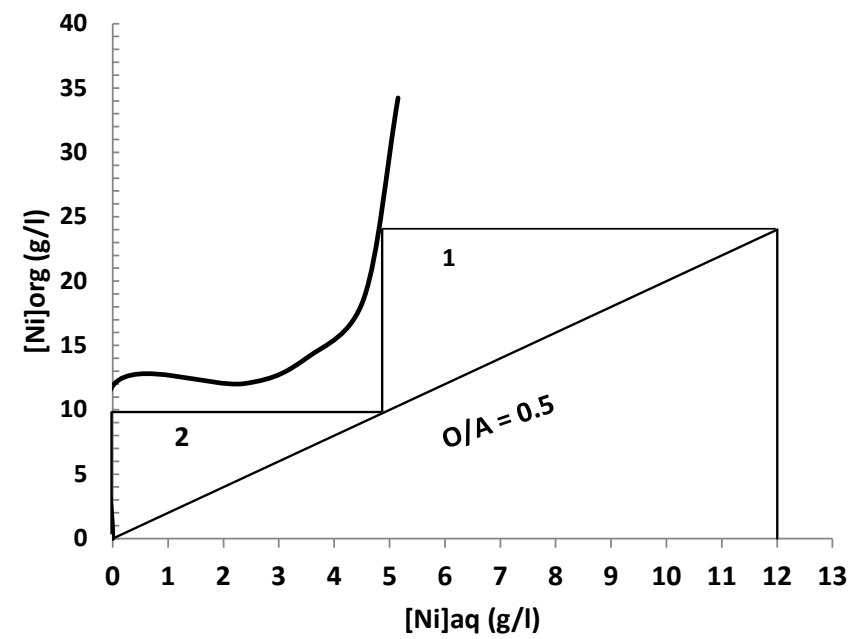

Figure 12. McCabe-Thiele Diagram constructed for nickel extraction at $\mathrm{pH} 8.75$, temperature of $55^{\circ} \mathrm{C}$ and LIX 84-ICNS of $40 \%$ (v/v).

$55^{\circ} \mathrm{C}$ and $\mathrm{O} / \mathrm{A}$ ratio 0.5. This investigation results demonstrate the advantage of LIX 84-ICNS in comparison to other extractants used previously for extracting nickel in ammoniacal solutions [8] [9]. Kumar et al. reported that by using LIX 84 of $10 \%(\mathrm{v} / \mathrm{v})$, maximum Ni extraction was obtained at two stage extraction under O/A ratio of 2 [8]. Parija et al. that used LIX 84-I 30\% (v/v) reported three stage of extraction to obtain a maximum nickel extraction from the ammonium sulphate solution containing $20 \mathrm{~g} / \mathrm{l} \mathrm{Ni}$ at $\mathrm{O} / \mathrm{A}$ ratio of 0.8 [9]. In industrial practice, QNI Yabulu that used LIX 87-QN at 30\% (v/v) and O/A 1.5 requires three stage extraction to get a maximum Ni extraction [14].

\subsection{Stripping Behaviour of Nickel and Cobalt by Sulfuric Acid}

Loaded organic phase was stripped under variations of $\mathrm{H}_{2} \mathrm{SO}_{4}$ concentrations at temperature of $80^{\circ} \mathrm{C}$ and $\mathrm{O} / \mathrm{A}$ ratio 1/1. Profiles of nickel and cobalt stripping percentage as a function of $\mathrm{H}_{2} \mathrm{SO}_{4}$ concentration are presented in Figure 13. It can be seen that the increase of $\mathrm{H}_{2} \mathrm{SO}_{4}$ concentration from 50 to $200 \mathrm{~g} / \mathrm{l}$ enhances stripping percentage of nickel from $46.22 \%$ to $98.22 \%$, while cobalt stripping at $200 \mathrm{~g} / \mathrm{H}_{2} \mathrm{SO}_{4}$ was only $3.16 \%$. At $200 \mathrm{~g} / \mathrm{l}$ of $\mathrm{H}_{2} \mathrm{SO}_{4}$, separation factor of $\mathrm{Ni}-\mathrm{Co}\left(\beta_{\mathrm{Ni}-\mathrm{Co}_{0}}\right)$ is 2568 . $\mathrm{Co}^{2+}$ that is co-extracted with nickel as $\mathrm{R}_{2} \mathrm{Co}$ chelate will be 
rapidly converted in the organic phase to $\mathrm{R}_{3} \mathrm{Co}$ chelate. This phenomenon leads to low levels of cobalt stripping. When cobalt is in $\mathrm{R}_{3} \mathrm{Co}$ form, the stripping kinetics of is very slow [12]. Cobalt accumulated in the organic phase will increase viscosity of the organic solution [12]. In this regard, the effective way to separate cobalt from nickel in ammoniacal solutions is by performing pre-oxidations prior to the extraction stage.

Stripping isotherm diagram for nickel was constructed based on the data obtained from the stripping testworks at temperature of $80^{\circ} \mathrm{C}, 200 \mathrm{~g} / \mathrm{H} \mathrm{H}_{2} \mathrm{SO}_{4}$, and $\mathrm{O} / \mathrm{A}$ ratios between $1 / 1$ and 5/1 by keeping the organic phase at a constant volume. It was found that the increase of $\mathrm{O} / \mathrm{A}$ ratios beyond unity decreases stripping percentage of nickel as illustrated in Figure 14. The McCabe-Thiele Diagram for nickel stripping was constructed as shown in Figure 15. Based on the constructed McCabe-Thiele Diagram, nickel stripping of higher than $99.9 \%$ can be obtained by two-stage stripping at $\mathrm{O} / \mathrm{A}$ ratio of $2 / 1$.

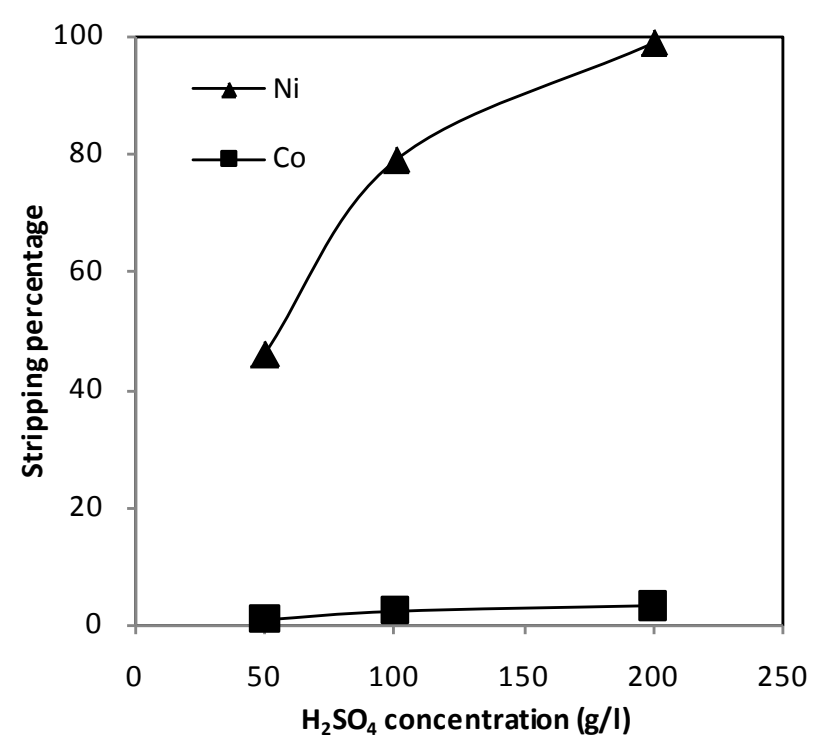

Figure 13. Profiles of nickel and cobalt stripping percentage as a function of $\mathrm{H}_{2} \mathrm{SO}_{4}$ concentration at temperature of $80^{\circ} \mathrm{C}$ and $\mathrm{O} / \mathrm{A}$ ratio $1 / 1$.

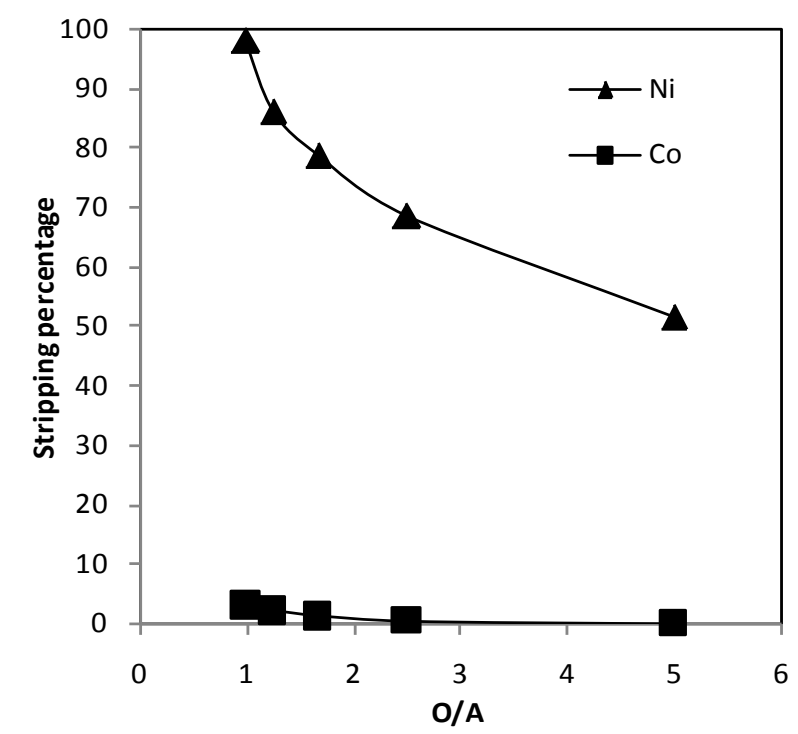

Figure 14. Profiles of nickel and cobalt stripping percentages as a function $\mathrm{O} / \mathrm{A}$ ratio at $\mathrm{H}_{2} \mathrm{SO}_{4}$ concentration of $200 \mathrm{~g} / \mathrm{l}$ and temperature of $80^{\circ} \mathrm{C}$. 


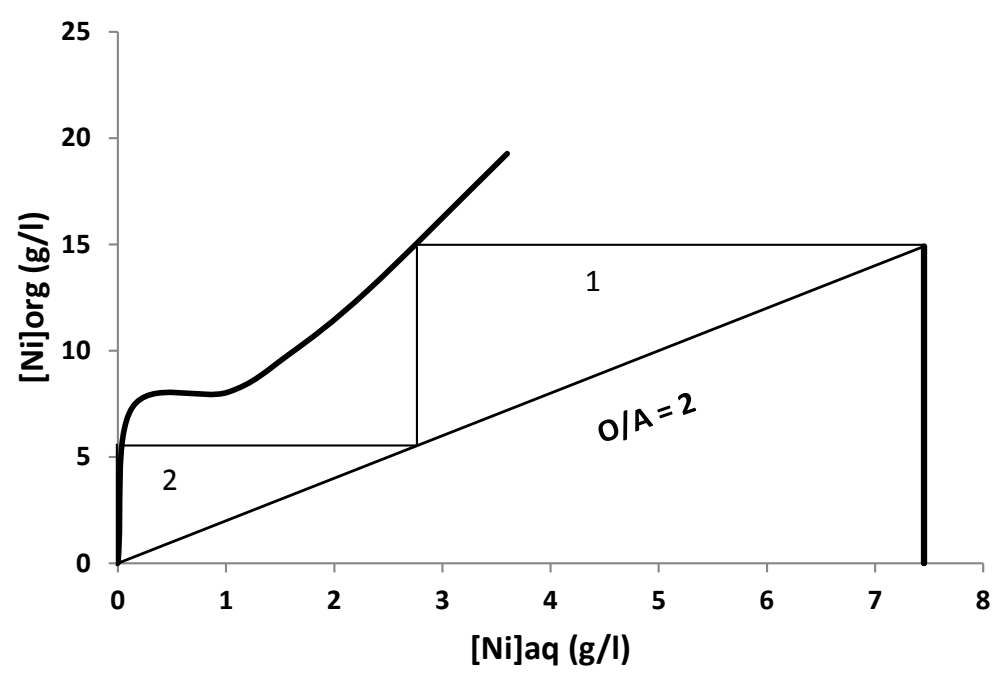

Figure 15. McCabe-Thiele Diagram for nickel stripping at temperature of $80^{\circ} \mathrm{C}$ and $\mathrm{H}_{2} \mathrm{SO}_{4}$ concentration $200 \mathrm{~g} / \mathrm{l}$.

\section{Conclusion}

The extractions of nickel and cobalt by LIX 84-ICNS from ammonia-ammonium carbonate increase by the increase of aqueous solution $\mathrm{pH}$ until 8.75. At pH levels beyond 8.75, the extraction percentage of nickel and cobalt decreases due to the formation of nickel and cobalt ammine-complexes that are more stable in aqueous solution. Extractions of nickel and cobalt by LIX 84-ICNS from ammonia-ammonium carbonate solution are endothermic with enthalpies of +171.03 and $+7.64 \mathrm{~kJ} / \mathrm{mole}$, respectively. Temperature gives greater effect on nickel than cobalt. Pre-oxidation of cobalt in aqueous solution by $1 \%(\mathrm{v} / \mathrm{v}) 30 \mathrm{wt} \% \mathrm{H}_{2} \mathrm{O}_{2}$ significantly reduces co-extraction of cobalt from $90.3 \%$ to $30.3 \%$. Based on constructed McCabe-Thiele Diagram, nickel extraction levels of higher than $99.9 \%$ can be obtained in two-stage extraction at equilibrium $\mathrm{pH}$ of 8.75 , temperature of $55^{\circ} \mathrm{C}$ and $\mathrm{O} / \mathrm{A}$ ratio of $1 / 2$. Nickel stripping of $98.22 \%$ was obtained at $\mathrm{H}_{2} \mathrm{SO}_{4}$ concentration of $200 \mathrm{~g} / \mathrm{l}$, temperature of $80^{\circ} \mathrm{C}, \mathrm{O} / \mathrm{A}$ of $1 / 1$ with co-stripped cobalt of $3.16 \%$. Based on constructed McCabe-Thiele Diagram, nickel stripping higher than $99.9 \%$ can be obtained by two-stage stripping using $200 \mathrm{~g} / \mathrm{l}_{2} \mathrm{SO}_{4}$ at $\mathrm{O} / \mathrm{A}$ ratio of $2 / 1$ and temperature of $80^{\circ} \mathrm{C}$.

\section{Acknowledgements}

The authors thank BASF that has provided LIX 84-ICNS extractant and shellsol as diluents used in this research work.

\section{References}

[1] Dalvi, A.D., Bacon, W.G. and Osborne, R.C. (2004) The Past and the Future of Nickel Laterites. PDAC 2004 International Conference Trade Show and Investors Exchange, Toronto, 7-10 March 2004, 1-27.

[2] Yildirim, H., Morcali, H., Turan, A. and Yucel, O. (2013) Nickel Pig Iron Production from Lateritic Nickel Ores. Proceedings of the Thirteenth International Ferroalloys Congress: Efficient Technologies in Ferroalloy Industry, Almaty, 9-13 June 2013, 237-244.

[3] McDonald, R. and Whittington, B. (2008) Atmospheric Acid Leaching of Nickel Laterites Review. Part I. Sulphuric Acid Technologies. Hydrometallurgy, 91, 35-55. http://dx.doi.org/10.1016/j.hydromet.2007.11.009

[4] McDonald, R. and Whittington, B. (2008) Atmospheric Acid Leaching of Nickel Laterites Review. Part II. Chloride and Bio-Technologies. Hydrometallurgy, 91, 56-69. http://dx.doi.org/10.1016/j.hydromet.2007.11.010

[5] Direct Nickel (2014). http://www.directnickel.com/our-process/

[6] Przeszlakowski, S. and Wydra, H. (1982) Extraction of Nickel, Cobalt, and Other Metals (Cu, Zn, Fe) with a Commercial $\beta$-Diketone Extractant. Hydrometallurgy, 8, 49-64. 
[7] Hu, J., Chen, Q., Hu, H., Qiu, B., Xie, A. and Yin, Z. (2012) Extraction Behaviour of Nickel in Ammoniacal Sulfate Solution with Sterically Hindered $\beta$-Diketone. Separation and Purification Technology, 95, 136-143. http://dx.doi.org/10.1016/j.seppur.2012.05.007

[8] Kumar, V., Pandey, B.D. and Bagchi, D. (1991) Application of LIX 84 for Separation of Copper, Nickel, and Cobalt in Ammoniacal Leaching of Ocean Nodules. Materials Transactions, 32, 157-163. http://dx.doi.org/10.2320/matertrans1989.32.157

[9] Parija, C., Reddy, B.R. and Sarma, P.V.R.B. (1998) Recovery of Nickel from Solution Containing Ammonium Sulphate using LIX84I. Hydrometallurgy, 49, 255-261. http://dx.doi.org/10.1016/S0304-386X(98)00027-9

[10] Alguacil, F.J. and Cobo, A. (1998) Extraction of Nickel from Ammoniacal/Ammonium Carbonate Solutions Using Acorga M5640 in Iberfluid. Hydrometallurgy, 50, 143-151. http://dx.doi.org/10.1016/S0304-386X(98)00047-4

[11] Sridhar, V., Verma, J.K. and Shenoy, N.S. (2010) Separation of Nickel from Copper in Ammoniacal/Ammonium Carbonate Solution using ACORGA M5640 by Selective Stripping. Minerals Engineering, 23, 454-456. http://dx.doi.org/10.1016/j.mineng.2009.12.001

[12] Mackenzie, M., Virnig, M. and Feather, A. (2006) The Recovery of Nickel from High-Pressure Acid Leach Solutions Using Mixed Hydroxide Product-LIX ${ }^{\circledR}$ 84-INS Technology. Minerals Engineering, 19, 1220-1233. http://dx.doi.org/10.1016/j.mineng.2006.01.003

[13] Flett, D.S. (2004) Cobalt-Nickel Separation in Hydrometallurgy: A Review. Chemistry for Sustainable Development, 12, 81-91.

[14] Fittock, J.E. (1992) Nickel and Cobalt Refining at QNI Pty Ltd Yabulu Queensland. AUSIMM Monograph, 19, 1-47.

[15] Habashi, F. (1997) Handbook of Extractive Metallurgi, Volume II: Primary Metals, Secondary Metals, Light Metals. Wiley-VCH, Heidelberg.

[16] Nathsarma, K.C. and Sarma, P.V.R. (1993) Processing of Ammoniacal Solutions Containing Copper, Nickel, and Cobalt for Metal Separation. Hydrometallurgy, 33, 197-210. http://dx.doi.org/10.1016/0304-386X(93)90014-5

[17] Alguacil, F.J. and Cobo, A. (1998) Separation of Copper and Nickel from Ammoniacal/Ammonium Carbonate Solutions Using Acorga PT5050. Separation Science and Technology, 33, 2257-2264. http://dx.doi.org/10.1080/01496399808545726

[18] LIX $84{ }^{\circledR}$-ICNS Technical Information, Global Mining Solution-BASF, 2013. www.basf.com/miningsolutions 